\title{
Fast-breeder test reactor faces licence refusal in Germany
}

Munich

THE West German state of North RhineWestphalia intends to refuse the "overall approval" necessary for operating the nearly completed fast-breeder reactor at Kalkar. This was announced in Düsseldorf on 1 April by the state Economics Minister Reimut Jochimsen, a Social Democrat (SPD).

The 300 -MW plant at Kalkar is $70 \mathrm{~km}$ west of Düsseldorf, not far from the Dutch border. Under construction since 1972, it has cost roughly DM6,500 million so far. The bulk of the funds has come from the Ministry for Research and Technology (BMFT). The reactor is meant as a test reactor for fast-breeder technology.

What Jochimsen says does not necessarily mean the end for the fast breeder. He has given the plant's principal owner, Schnellbrüter-Kernkraftwerksgesellschaft (SBK), until 30 June to respond to his complaints. Jochimsen claimed that there have been 2,000 unauthorized alterations in the reactor's construction and that Kalkar's design is uncomfortably similar to that of Reactor 4 at Chernobyl.

The plan to prevent Kalkar from going into operation was criticized as a political ploy. SBK's technical director Werner Koop pointed out that the 2,000 changes cited have occurred over a period of 15 years, during which time some 500 tonnes of reports have been delivered to the state government. Most of the changes, said Koop, do not even require approval from

\section{Unexpected windfall for Pasteur Institute}

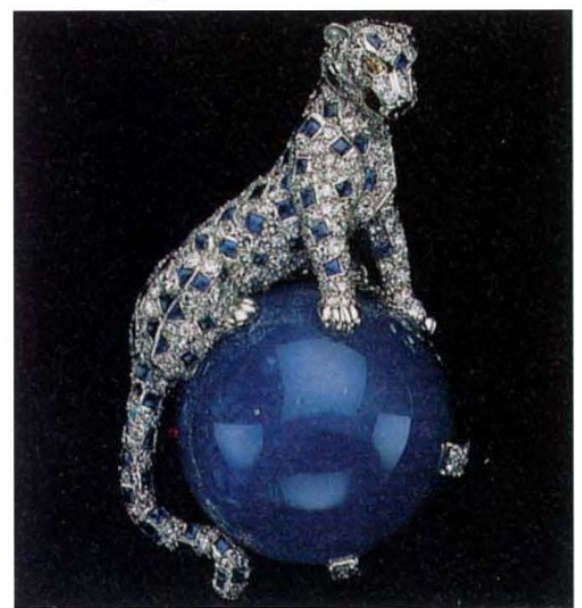

London

LAST week's auction of the Duchess of Windsor's jewellery has brought a windfall for the Pasteur Institute in its centenary year. In her will, the duchess directed that almost all the proceeds of the sale, expected to be about $£ 5$ million, should go

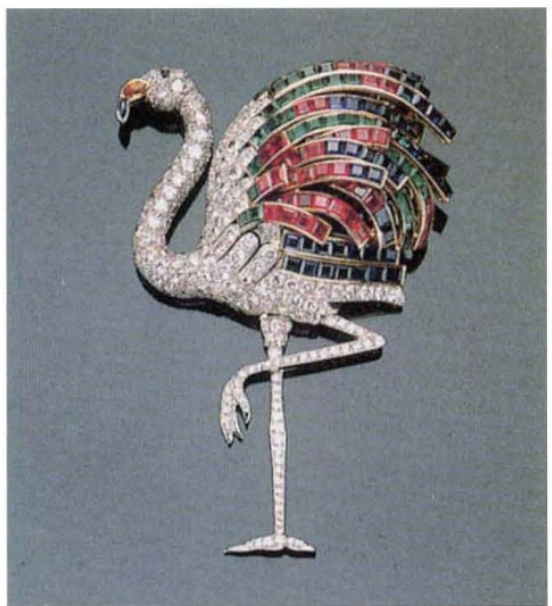

the state licensing authorities.

Rolf Hüper, a scientist in West Germany's Nuclear Research Centre (KfK) at Karlsruhe, said that all of the comparisons of Kalkar with Chernobyl have been dealt with. For example, it is not so alarming that the plant at Kalkar uses sodium as a coolant in the light of experience at the

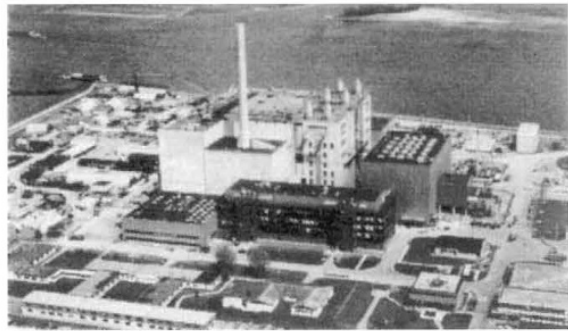

The nearly completed fast-breeder reactor in Kalkar.

Soviet BN 350 fast breeder on the Caspian Sea, where a sodium-water explosion "in tonne quantities" occurred without any release of radioactivity.

Elections are not due in North RhineWestphalia until 1990, but Social Democrats were facing a tough election in the neighbouring state of Hesse on 5 April. Jochimsen's announcement may have been a way to win support for the SPD from anti-nuclear voters, particularly supporters of the Green party.

A decision to refuse to license the $\mathrm{Kal}$ kar plant would put North Rhine-Westphalia's government on a collision course with the West German government. But

to the Pasteur. The auction raised $£ 31$ million. A new $£ 8$-million department for the study of retroviruses and AIDS (and, perhaps, cancer) will go ahead. The rest of the money may simply be invested to support the department, which will employ 50-100 scientists. the federal Environment Minister, Walter Wallmann (Christian Democrat), has not yet said that he would try to force Jochimsen to license the plant, saying instead that he would wait until the summer before deciding on a course of action. If Jochimsen stands firm, the dispute could wind up before the German Supreme Court at Karlsruhe, just like the suit brought by the state of Hesse challenging West Germany's "plutonium economy".

BMFT would like to see the reactor licensed. A spokeswoman for the ministry said, "we have an interest... in seeing the breeder go into operation, but that does not mean we will finance it".

SBK's Koop said that the current financing of the Kalkar reactor will hold out until April 1988. Each month's delay, however, costs an extra DM10 million.

In the end, costs rather than politics may decide the fate of the reactor. With the cost of both Kalkar and the reprocessing plant at Wackersdorf far above the original estimates, the West German government may have to rethink its plans to build a larger breeder in partnership with France.

Steven Dickman

\section{The costs of nuclear decommisioning}

\section{London}

THE means of determining the cost of decommissioning a Magnox nuclear power station and the period over which that cost can be spread has been seriously challenged by the UK House of Commons Energy Committee. In a report published on 1 April the committee concludes that the only real way to assess the economic viability of a nuclear plant is by "discounting of future decommissioning costs"

Central Electricity Generating Board (CEGB) policy calls for the final stages of dismantling and disposal of the reactor core to be delayed by a century, allowing radioactivity to decay to a low level.

The committee concludes that there is no realistic alternative in assessing the economics of a reactor but it has challenged the relevance of this method over a period longer than 50 years. And says that "it is essentially an accounting exercise which pays no regard to questions of moral responsibility to future generations. It is scarcely possible to believe that the coal owners of 1887 made assumptions about the value to us of coal."

In evidence to the committee, the CEGB had challenged press reports which claimed that decommissioning would cost $£ 2,700$ million (1984-85 figures) a station, they estimated a maximum of $£ 330$ million and environmental lobby groups provided estimates of between $£ 500$ million and $£ 1,000$ million based on 1986 figures. Variations are also due to alternative ways of performing the decommissioning.

Bill Johnstone 